\title{
Corporate responsibility, supply chain partnership and performance: an empirical examination
}

\author{
David Gallear ${ }^{1}{ }^{\mathrm{a}},{ }^{\text {Abby Ghobadian }}{ }^{\mathrm{b}}$, Weifeng Chen ${ }^{\mathrm{c}}$ \\ ${ }^{a, c}$ Brunel Business School, Brunel University, Kingston Lane, Uxbridge Middlesex, UB8 3PH, UK \\ ${ }^{b}$ Henley Business School, University of Reading, Greenlands, Henley-on-Thames, Oxfordshire, RG9
}

$3 A U, U K$

\begin{abstract}
Unlike corporate and business levels, there is little research examining corporate responsibility (CR) at the functional level of the firm including supply chain strategy. The results of a firm-level survey show that $C R$ internal awareness, and monitoring CR performance are positively related to the supply chain partnership approach, however sharing CR best practices is negatively associated. Furthermore, the impact of $\mathrm{CR}$ on firm performance is mediated by the functional behaviour of supply chain partnership formation. Our study provides support for including CR awareness building and monitoring in the development of partnerships but cautions against imposing CR best practices on suppliers.
\end{abstract}

\footnotetext{
${ }^{1}$ *Corresponding author: David Gallear, Brunel Business School, Brunel University, Kingston Lane, Uxbridge Middlesex, UB8 3PH, UK. Email: David.Gallear@brunel.ac.uk. Tel. +44 (0) 1895 267077. Fax. +44 (0)1895 269775.

Other authors: abby.ghobadian@henley.reading.ac.uk; Weifeng.Chen@brunel.ac.uk
} 


\title{
Corporate responsibility, supply chain partnership and performance: an empirical examination
}

\begin{abstract}
Unlike corporate and business levels, there is little research examining corporate responsibility (CR) at the functional level of the firm including supply chain strategy. The results of a firm-level survey show that $C R$ internal awareness, and monitoring $C R$ performance are positively related to the supply chain partnership approach, however sharing CR best practices is negatively associated. Furthermore, the impact of $\mathrm{CR}$ on firm performance is mediated by the functional behaviour of supply chain partnership formation. Our study provides support for including CR awareness building and monitoring in the development of partnerships but cautions against imposing CR best practices on suppliers.
\end{abstract}

Keywords: corporate responsibility; supply chain; partnerships; monitoring best practices; performance.

\section{Introduction}

To maximise their operational efficiency and effectiveness, firms in supply chains have turned to closer collaborative relationships with their suppliers (Szwejczewski et al., 2005). In parallel over the last few decades, consumer pressure, public concern, regulatory forces, industry peer pressures, perceived market advantage, reputation concerns and media interest (Banerjee et al., 2003;

Dummett, 2006; Park-Poaps and Rees, 2010) have heightened firms' appreciation of the importance of corporate (ethical and environmental) responsibility. This has led to the prevalence of corporate responsibility on firms' top management agendas (McWilliams and Siegel, 2001), and recent research suggests that corporate responsibility issues have become an increasingly more significant part of strategy in large and small companies alike (Carlisle and Faulkner, 2004; Petts et al., 1999).

The extant strategy literature identifies three levels of strategy. These are corporate, business, and functional (Hofer and Schendel, 1978). A great deal of research considers corporate responsibility at the organisational level and considers its interaction with corporate or business strategy (Laplume et al., 2008). The examination of corporate responsibility and functional strategies is much less prevalent. Strategy at a functional level focuses on the maximisation of resource productivity within 
the function in question, for example, operations and marketing (Hofer and Schendel, 1978). It is generally assumed that functional strategies are derived from the business level strategy (Fitzsimmons et al., 1992). Purchasing, more recently referred to as supply management, is recognised as one of the core functional strategies of the firm (Virolainen, 1998; Baier et al., 2008). In this paper we examine the relationship between firms' corporate (ethical and environmental) responsibility attitudes, policies and practices towards suppliers and the supply chain partnership strategy.

Corporate responsibility consists of a matrix of strategies, policies and behaviours. What is clear from the corporate responsibility literature is that corporate responsibility is a way of managing relationships with stakeholders (Waddock, 2004). It is a signal to stakeholders that the firm will not betray their interests. As such, corporate responsibility shares some of the central tenets of the partnership relationship approach, notably fair treatment and collaboration. Corporate responsibility is often said to increase trust in, and support for, organisations (McWilliams et al., 2006). It facilitates the development of trusting relationships with key stakeholders based on the principles of distributional, procedural, and interactional justice, increasing the likelihood of nuanced information sharing, in turn spurring innovation and enabling the organisation to better deal with environmental change (Harrison et al., 2010). We would therefore expect that firms exhibiting corporate responsibility would also exhibit a tendency towards relationships based on a partnering ethos. That is, we would expect that firms that put into place corporate responsibility practices at the functional level of purchasing and supply management are more likely to be in close partnership with their suppliers than those firms where corporate responsibility practices are less prevalent.

To contribute to the development of SCM as a discipline in its own right by explicitly recognising linkages to other disciplines (Vachon and Klassen, 2006) we examine how the assimilation of a supply chain partnership approach is affected by corporate responsibility practices. We attempt to identify the impact of different facets of corporate responsibility on supply chain partnership. With more and more firms recognising the market and economic benefits that can be derived from partnering (Carr and Pearson, 2002), knowing how to move towards and facilitate partnership relationships with suppliers has become a high priority and vital challenge for firms. However, the extant literature on corporate responsibility in the buyer-supplier relationship domain provides only limited insights into how the efforts of firms to make 'corporate responsibility' operational affects the relationship between buyer and supplier. It is the contention of this study that increased levels of corporate responsibility internal awareness, corporate responsibility monitoring and corporate responsibility best practice sharing will result in greater levels of supply chain partnerships between a firm and its 
suppliers. We also assess the impact of corporate responsibility and supply chain partnership formation on firm performance (see Figure 1). Through these efforts, we attempt to enrich the understanding of how firms' ethical and environmental practices support or otherwise the development of partnerships with suppliers and how these partnerships affect firm performance.

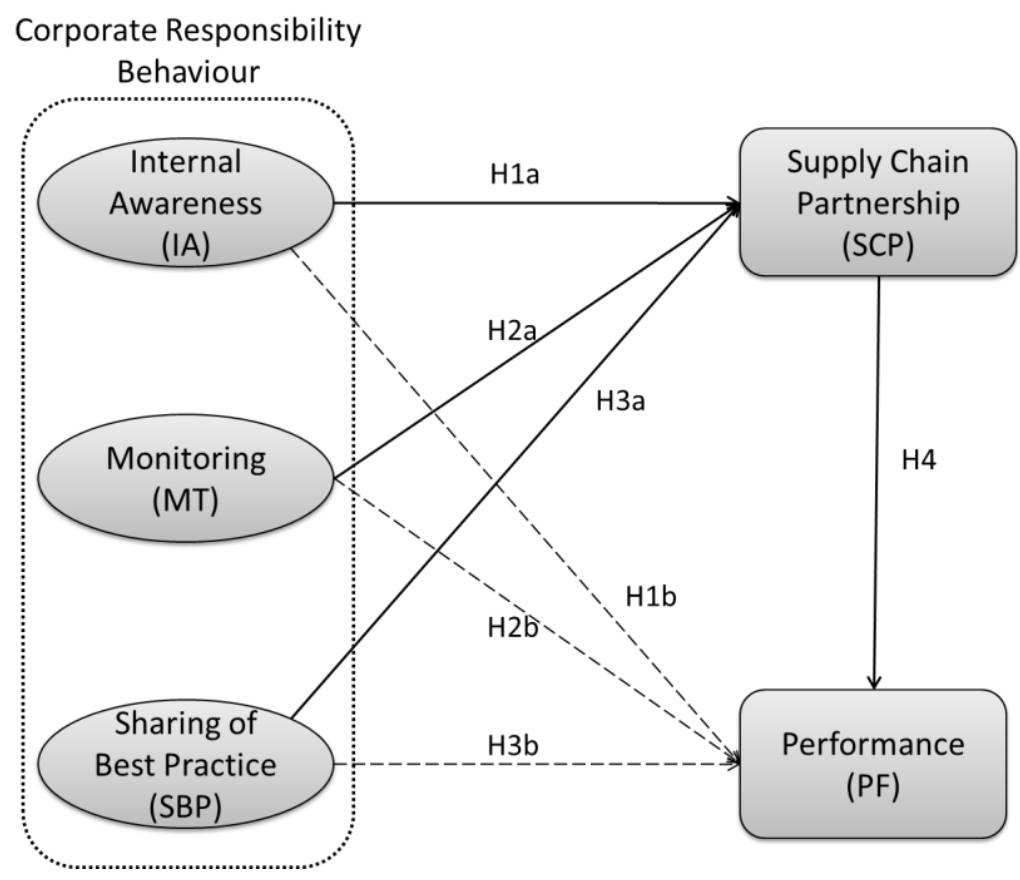

Figure 1 - Conceptual model

\section{Conceptual development}

\section{Supply chain partnership}

This study is concerned with a specific type of inter-organisational exchange relationship referred to as supply chain partnerships. Squire et al (2009) note that the type of relationship between a buyer and supplier can vary from adversarial to cooperative (Carr and Pearson, 2002). In the adversarial approach, high levels of competition, price bargaining and continuity of supply are achieved through having a large number of suppliers and this approach is suitable where low value or low risk parts are required (Squire et al, 2009). Supply chain partnerships operate at the cooperative end of the spectrum and are strategic in nature and purpose. They are likely to be preferred when items need to be sourced that are strategic in terms of their importance to the organisation and/or the complexity of the supply market, either because there are limited sources in the market place or because supply is at risk (Squire et al, 2009). 
Within the context of cooperation, relationships between firms and their suppliers can occur in a variety of forms. The literature on the development of cooperative relationships notes the emergence of two broad perspectives - contractually based and non-contractually based. In this paper we focus on the more ubiquitous type, the non-contractual supply chain partnership approach. The former, such as joint ventures or strategic alliances, involve the negotiation and maintenance of explicit contracts that detail expectations and deliverables and sometimes revenue share (Chauhan and Proth, 2005) and they have legal structures that define their boundaries (Wilson, 1995). Supply chain partnerships on the other hand tend to operate without a formal contract (Lambert et al, 1996) and seldom involve any direct equity investment (Stuart, 1997). Mohr and Spekman (1994) define partnerships as 'purposive strategic relationships between independent firms who share compatible goals, strive for mutual benefit, and acknowledge a high level of mutual interdependence'. By joining efforts they seek to achieve goals that each firm, acting alone, could not easily attain (Mohr and Spekman, 1994).

The characteristics of supply chain partnerships have been widely explored in the literature (e.g. MacDonald, 1999; Szwejczewski et al., 2005), and a number of partnership development models are proposed (e.g. Lambert et al., 1996; Tuten and Urban, 2001). There is also a wealth of literature on the motivations for firms to develop partnerships with selected suppliers (Mohr and Spekman, 1994) rooted in transaction cost economics (e.g. Williamson, 1985), competitive strategy (e.g. Porter, 1980) and resource dependence theories (e.g. Pfeffer and Salancik, 1978). However, beyond these key antecedents of strategic buyer-supplier relationship formation which tend to dominate in the literature, the influence of other factors that are prevalent in today's business environment on the development of a supply chain partnership ethos between firms is lacking. The factor we focus on in this study is the influence of corporate responsibility. In the remainder of this section we develop our conceptual model of the influence of corporate responsibility on supply chain partnerships and set our hypotheses.

\section{Corporate responsibility - ethical and environmental behaviour}

Corporate Responsibility (CR) has emerged from a series of developments over the last few decades, notably the development of corporate social responsibility (CSR) and the synergies between CSR and strategic management's 'stakeholder' concept.

CSR has its roots in business and society literature (Andriof and Waddock, 2002). The concept attracted considerable academic interest in the 1950s/1960s (McGuire, 1963) with early work based 
on the social contract theory (Eells and Walton, 1961; Elbing and Elbing, 1964) and moral agency theory (French, 1979). The basic premise was that business should be of service to the larger community. However, the concept attracted considerable criticism because of it vagueness and disconnection with firms' economic responsibilities (Levitt, 1958; Friedman, 1962).

From the late 1970s the field witnessed a number of notable conceptual developments. These included the development of Corporate Social Performance (CSP) by Carroll (1979), Wartick and Cochran (1985) and Wood (1991). Carroll (1979) proposed a multidimensional model encompassing four aspects of responsibility: economic; legal; ethical and discretionary. Wartick and Cochran (1985) highlighted relevant issues through a process of analysis. Wood (1991) combined content and process insights and proposed a set of principles of engagement. The key messages of this work were that businesses need to reflect on the nature of their responsibilities and analyse, measure and monitor social issues (Wartick and Cochran, 1985; Wood, 1991), and to develop an appropriate response style to public expectations in areas not clearly defined by law (e.g. Preston and Post, 1975; Frederick, 1978).

In parallel with the business and society field, the "stakeholder" concept was taking root in the strategic management field. Taylor (1971), in a review of corporate strategy practices, suggested that the importance of stakeholders would eventually result in a planning approach that incorporated a broader group of stakeholders' interests. Freeman's (1984) seminal work placed the stakeholder concept among the key strategy concepts. Stakeholder theorists view the firm as a nexus of relationships based around the core thesis that business organisations have obligations to shareholders and a wider group of stakeholders (Jones, 1995). Freeman (1984) defined a stakeholder as any group or individual who can affect or is affected by the achievement of the organisation's objectives.

The two fields converged towards each other when influential scholars highlighted their synergy. Wood and Jones (1995), for example, argued that the role of stakeholders was relevant to the study of CSR in three important ways: (1) as a source of expectations about what constitutes desirable and undesirable firm performance, (2) as the recipients of corporate actions and outputs, therefore experiencing the effects of corporate behaviour and (3) as evaluators of how well organisations have met expectations and / or how organisational behaviours have affected the groups and organisations in their environment.

The definition of stakeholder offered by Freeman (1984) was too broad to be of practical help to organisations and subsequently Mitchell et al (1997) proposed the salience theory. This offered an 
effective and simple approach to ranking stakeholders according to their importance to the organisation. Stakeholder theory classifies suppliers as 'dominant stakeholders' because they possess power and legitimacy. Therefore, suppliers are an integral part of corporate responsibility and strategy considerations.

The extant literature offers a number of corporate responsibility definitions and one of the most widely used definitions is the definition put forward by Waddock (2004). She argued for a change in terminology from CSR to "corporate responsibility" because CSR implies the discretionary responsibilities of business towards stakeholders while corporate responsibility reflects the idea that responsibilities are integral to corporate actions, decision, and behaviours. She defined corporate responsibility as "the degree of (ir)responsibility manifested in a company's strategies and operating practices as they impact stakeholders and the natural environment day to day" (p. 10). That is, strategies and operating practices that a company develops in its efforts to deal with and create relationships with its numerous stakeholders and the natural environment. This definition supports the operationalization of the concept in an organisational setting and we used this definition to operationalise corporate responsibility in the context of suppliers.

\section{Three corporate responsibility $(C R)$ dimensions}

Our review of the literature points to three key facets of corporate responsibility (CR) in the context of strategies and operating practices supporting buyer-supplier relationship development. These are: developing internal awareness, measurement and feedback (monitoring), and sharing of best practices. These three facets are evident in the corporate responsibility development processes put forward by a number of scholars. Carlisle and Faulkner (2004) identify a process leading from developing and promoting awareness, through initial implementation that includes developing quantifiable measures, to mainstreaming. They argue that in this process, structural changes coupled with increasingly effective practices to promote ethical behaviour can lead to a more ethical and fair treatment ethos. Park-Poaps and Rees (2010) in their study of responsible supply chain management orientation from the fair treatment of suppliers/labour perspective confirmed two salient dimensions, internal direction and awareness practices and external partnership practices. Vachon and Klassen's (2006) work on extending green practices from firms to their supply chain partners identified monitoring and collaboration as two sets of environmental practices/activities supporting greater integration, also noting that the internalisation (i.e. monitoring) and externalisation (i.e. collaboration) framework that underpinned their model had previously been used in supplier development research (Krause et al., 2000) and in corporate responsibility (Husted, 
2003). Based on these prior works, internal awareness, monitoring, and sharing of best practices were identified as the corporate responsibility constructs in our research framework.

Internal awareness

The visible actions and behaviours of firms are an indicator to other stakeholders of what that firm values and how it is likely to behave towards them (Morsing and Schultz, 2006; Turban and Greening, 1997). The literature supports the proposition that corporate responsible behaviours engender confidence in a firm because they signal to stakeholders the likelihood of receiving fair treatment (Ahmad, et al., 2003; Orlitzky et al., 2003; Sharma and Vredenburg, 1998). That signal is conveyed through various mechanisms. On the one hand through deliberate and planned external communications. On the other, through direct contact between employees of the firm and its stakeholders. As such, the confidence will be affected by the extent to which the firms' employees themselves are aware of the firms' corporate responsibility values and orientation (Hopkins, 2005). A developing awareness of the importance of ethical issues, for example, can lead to the formulation of policies which are subsequently linked to mission statements (Carlisle and Faulkner, 2004) and that cascade into internal training programmes. Internal awareness can be created through a variety of mechanisms, for example appointing someone to oversee policy (Carlisle and Faulkner, 2004), publishing and publicising ethical and environmental reports (Carlisle and Faulkner, 2004), clear policy statements on acceptable practices (Park-Poaps and Rees, 2010) and training programmes (Madsen and Ulhoi, 2001). Accordingly, the firm's use of mechanisms and practices promoting internal awareness of corporate responsible behaviour are a signal to suppliers that the firm values fair treatment and cooperation for mutual benefit. It follows that:

Hypothesis 1a: The internal awareness of corporate responsibility values and outcomes is positively related to the incidence of the supply chain partnership approach.

Monitoring

There is strong agreement in the literature that monitoring is an essential part of any effort to raise the level of corporate responsible behaviour in organisations (Waddock et al., 2002), and the literature associated with the monitoring of suppliers is extensive (e.g. Talluri and Sarkis, 2002).

Monitoring is closely associated with compliance. That is, firms monitor their existing behaviour and that of other stakeholders to ascertain, or to ensure, that the behaviour is acceptable and conforms to what is expected (Lebas, 1995). It is reasonable to argue that for firms who enter into supply chain partnerships with their suppliers, the corporate responsibility of these partners is an important 
consideration. To enter into a partnership a supplier must be able to demonstrate corporate responsible policies, practices and behaviours to the satisfaction of the buyer. Consequently, a supplier is unlikely to be able to enter into a supply chain partnership with a buyer if it doesn't reach at least a minimum acceptable level of corporate responsible behaviour. The economic implication of monitoring corporate responsible behaviour is therefore obvious (Boyd et al., 2007). It follows that monitoring corporate responsible behaviour is not just a passive exercise, but plays an important role in the selection of partners (Noci, 1997). Suppliers' willingness to engage in monitoring signals their disposition to a close and cooperative working relationship, and vice versa signals a firm's willingness to extend its monitoring practices and involve its suppliers in corporate responsibility monitoring. The existence of monitoring practices between a buyer and supplier indicates that the relationship is not a one-off relationship, but instead a relationship with a long term outlook, that is, with a partnering perspective.

Hypothesis 2a: The monitoring of corporate responsibility performance is positively related to the incidence of the supply chain partnership approach.

Sharing of best practice

The sharing of know-how is an important aspect of supply chain management (Akumen and Dale, 1995). The extant literature suggests that supply chain partners exchange information with regard to practices that lead to greater efficiency and effectiveness (Sohal et al, 1998). However, knowledge exchange is broader than efficiency and effectiveness and also includes best practices (Sohal et al, 1998). An issue which has not received a great deal of attention is the extent by which corporate responsibility best practices forms part of this exchange process. On the one hand it is reasonable to argue that the spread of corporate responsibility can be directed more easily when a firm has partnerships with its suppliers as opposed to other forms of relationships, particularly those of an adversarial nature. On the other hand, it is reasonable to argue that when firms promote the implementation of corporate responsibility best practices within their relationships with suppliers, thereby seeking to enhance the depth of knowledge sharing and the embeddedness of mutually beneficial practices, they would be more likely also to facilitate the development of a supply chain partnering ethos. For example, seeking supplier accreditation to the ISO14000 Environmental Systems Standard has emerged as a best practice for firms when identifying long term (preferred) supply partners. Other corporate responsibility best practices stimulating two way exchange and problem solving and enhancing development of joint capabilities are the engagement of suppliers as equal partners in joint training programmes (Carr et al., 2008), and the inclusion of ethical and environmental standards in collaborative activities (Zineldin and Bredenlow, 2003). Sharing of best 
practices is commonly agreed as a vehicle augmenting closer partnering (Szwejczewski et al, 2005). It follows that:

Hypothesis 3a: Sharing corporate responsibility best practices is positively related to the incidence of the supply chain partnership approach.

\section{Corporate responsibility and performance}

Numerous empirical studies (e.g. Berman et al., 1999; Hillman and Keim, 2001; Sisodia et al., 2007) and two recent meta-analyses (Margolis and Walsh, 2003; Orlitzky et al., 2003) all suggest that corporate responsibility has a positive impact on firms' performance. At the same time, a small number of studies have shown either a negative association between corporate responsibility and firms' performance or no association either way (Margolis and Walsh, 2003). These studies examined the relationship between corporate CR policy and firm's financial and market performance. Typical measures used to assess firms' corporate responsibility were: disclosure of social performance; expenditure on environmental practices; Fortune reputation rating; survey of environmental practices; Investor Responsibility Research Centre (IRRC) ratings; Council for Economic Priorities (CEP) rating; charitable contributions; and espoused commitment to ethics in annual reports (Margolis and Walsh, 2003). However, the majority of the studies used a single corporate level CR variable to assess corporate responsibility. We contend that the lack of empirical studies examining the relationship between functional level corporate responsibility policy/practices and firm performance represents a significant gap in the literature. In the absence of direct empirical evidence we formed the following hypotheses based on the two recent meta-analyses cited above that showed a modest positive association between corporate responsibility and firms' performance:

Hypothesis 1b: The internal awareness of corporate responsibility values and outcomes has a positive impact on firm performance.

Hypothesis $\mathbf{2 b}$ : The monitoring of corporate responsibility performance has a positive impact on firm performance.

Hypothesis $\mathbf{3 b}$ : Sharing corporate responsibility best practices has a positive impact on firm performance. 


\section{Supply chain partnership and performance}

Supply chain partnerships are designed to leverage the strategic and operational capabilities of individual participating organizations to help them achieve significant on-going benefits (Stuart, 1997). A partnership emphasizes direct, long-term association and encourages mutual planning and problem solving efforts (Gunasekaran et al., 2001). Partnerships with suppliers enable organizations to work more effectively with a few important suppliers who are willing to share responsibility for the success of the product offerings. Strategically aligned organizations can work closely together and eliminate wasteful time and effort. We expect that the adoption of partnerships with suppliers is beneficial to firm performance. As Carr and Pearson (2002) note, strategic purchasing and supplier relationships can add value to the firm. Organizational performance refers to how well an organization achieves its market-oriented goals as well as its financial goals (Yamin et al., 1999). The short-term objectives of supply management are primarily to increase productivity and reduce inventory and cycle time, while the long-term objectives are to increase market share and profits for all members of the supply chain (Tan et al., 1998). Financial metrics have served as a tool for comparing organizations and evaluating an organization's behaviour over time (Holmberg, 2000). Any organizational initiative, including supply chain management practices, should ultimately lead to enhanced organizational performance. A number of prior studies have measured organizational performance using both financial and market criteria, including return on investment (ROI), market share, profit margin on sales, the growth of ROI, the growth of sales, the growth of market share, and overall competitive position (Li et al., 2006; Stock et al. 2000). In line with the above literature, similar items (sales per employee and profit margin on sales) were adopted to measure organizational performance in this study. This leads to our final hypothesis:

Hypothesis 4: Prevalence of the supply chain partnership approach has a positive impact on firm performance.

\section{Research method}

Data collection

We developed a mail survey instrument to test the stated hypotheses. The cross-sectional nature of the study in which data was obtained from a large sample of organisations was a deliberate and important feature in adding to the extant knowledge. Senior managers/directors involved in supply management roles were the target respondents for the study. We adopted a single-informant approach consistent with other studies (Taylor, 2005). The sample was compiled with help from the 
UK Chartered Institute of Logistics and Transport. Their practitioner database was carefully scrutinised to ensure that only respondents capable of responding to the questions were selected. Only practising senior managers or directors directly employed in designated supply management roles were selected. Appropriate filters on job title and role were used to direct this process of selection. This step was taken to improve the quality of the responses and reduce the possibility of erroneous recall or respondent bias that can occur when a single informant is used (Fynes et al, 2005, Kumar et al., 1993). We encouraged completion of the questionnaire by offering and subsequently providing a summary of the study findings. Furthermore, to improve the response rate we undertook a repeat mailing of the questionnaire (Dillman, 2000). Following screening of the returns for respondents not meeting our informant selection criteria, the administration of the questionnaire yielded usable responses from 152 organisations.

\section{Measures and validity}

The study measures were developed following an in-depth review of corporate responsibility and supply chain partnership and related literature, as well as discussions with industry practitioners. The questionnaire items for corporate responsibility practices and supply chain partnership were measured using a five point scale anchored by ' $1=$ not at all' and ' $5=$ to a very great extent'. The measurement items are reported in the Appendix.

We measured supply chain partnership with five items adopted from the partnership literature. Drawing on the definition of partnership proposed by Mohr and Spekman (1994) and cited earlier, we surveyed the literature for a set of measures that could be used to indicate the presence of the partnership type relationship. After juxtaposing them against other contributions (e.g. Lambert et al, 1996) to check for construct validity a set of five items derived based on MacDonald (1999) were used.

We searched the literature for established measures of corporate responsible behaviour in the context of buyer-supplier relationships. We found that although the literature provided guidance, it was ultimately fragmented and underdeveloped in this respect. In developing our measures for corporate responsibility internal awareness, monitoring corporate responsibility performance and sharing corporate responsibility best practice we were therefore guided by input from expert practitioners. Starting with the supply chain corporate responsibility framework proposed by Hughes et al (1999) we juxtaposed the ethical / environmental behaviour items it identifies against the extant literature (see Three corporate responsibility (CR) dimensions section) to check for any obvious omissions. We then consulted a committee of practitioners comprising senior managers 
known to be operating in purchasing and supply management positions. Through discussions, and with minor adjustment, we were able to establish the validity of the proposed indicators as key practices and/or policies underpinning corporate responsibility in the domain of purchasing and supply management. Therefore, we used four items to measure practices and policies promoting corporate responsibility internal awareness, three items to measure firms' monitoring of corporate responsibility performance, and three items to measure the sharing of corporate responsibility best practices. All the composite reliabilities (ranging from 0.775 to 0.856 ) are greater than the 0.7 benchmark and the average variance extracted exceeded 0.50 , confirming the measures demonstrate adequate convergent validity and reliability (Fornell and Larker, 1981). As discussed earlier, firm performance was measured via two commonly used objective indicators: sales per employee and profit margin. The questionnaire was also pilot tested to check its suitability and appropriateness for the target population. Through this approach the content validity of the questionnaire was ensured. Table 1 reports the descriptive statistics and correlation matrix for all the measures. The correlations confirm the appropriateness of the data for analysis using multivariate approach.

$<$ Take in Table 1 about here >

\section{Results}

We tested the hypotheses using structural equation modelling (s.e.m.) with a maximum likelihood estimation option and our conceptual model (Figure 1) as the base model. The model fits the data satisfactorily $(\chi 2(152)=184.041, P<0.001, \mathrm{CMIN} / \mathrm{DF}=1.688, \mathrm{IFI}=0.941, \mathrm{CFI}=0.938, \mathrm{RMSEA}=0.067)$. The results are summarised in Table 2.

With regard to Hypothesis $1 \mathrm{a}$, Table 2 shows that internal awareness does have a positive effect on the incidence of the supply chain partnership approach, thus providing support for H1a. For Hypothesis $2 a$, which concerns the effect of monitoring corporate responsibility performance with suppliers/partners, we find that such monitoring is positively related to the incidence of the supply chain partnership approach, thus supporting H2a.

Hypothesis 3a pertains to the effects of sharing corporate responsibility best practices with suppliers/partners. The results show that there is a significant effect, however that sharing corporate responsibility best practices is, in fact, negatively related to the incidence of the supply chain partnership approach. This is a very interesting finding that we address in the next section. 
Based on the limited findings in the extant literature we also hypothesised $(\mathrm{H} 4)$ that the adoption of a supply chain partnership approach would have a positive impact on firm performance. The results from our sample indicate that this is the case, thus providing support for $\mathrm{H} 4$. We also hypothesised that each of our three corporate responsibility dimensions would have a positive impact on firm performance. As table 2 indicates, this was not the case. Neither corporate responsibility internal awareness, monitoring or best practice sharing had an effect on firm performance, thus providing no support for $\mathrm{H} 1 \mathrm{~b}, \mathrm{H} 2 \mathrm{~b}$ and $\mathrm{H} 3 \mathrm{~b}$.

$<$ Take in Table 2 about here $>$

\section{Discussion}

In this paper we assess the relationship between corporate responsibility and supply chain partnership and attempt to identify the impact of different facets of corporate responsibility on supply chain partnership development. Our study contributes to the literature in three main ways.

Firstly, our findings indicate that corporate responsibility does have an influence at the functional strategy level within the firm, in this case on supply chain partnership. The study has therefore established that the influence of corporate responsibility is not confined to the corporate and business strategy level of the organisation. This is an important finding because it adds weight to the credibility of corporate responsibility not just as a high level corporate and business level strategy ideal, but also as a concept that can directly affect the value adding operations level practices of the firm.

Secondly however, our findings indicate that corporate responsibility policies and practices have a mixed influence at the functional strategy level, and thereby add to the extant literature that cautions about the breadth of influence that corporate responsibility policies and practices presently have on core operations practices (Salzmann et al., 2005).

We found that the development of ethical and environmental awareness within the firm does increase the likelihood of closer relationship development with suppliers through supply chain partnerships. Firm's efforts to raise awareness amongst employees as a conduit for raising external perceptions, and firm's efforts to publicise their ethical and environmental statements to suppliers directly have an effect on suppliers' perception of the likelihood of receiving fair treatment from the buying firm. Our findings therefore also confirm the suitability of some established mechanisms firms use for signalling to external stakeholders their ethical and environmental credentials (Orlitzky 
et al., 2003; Sharma and Vredenburg, 1998). As evidenced in this study, these mechanisms are: appointing someone to oversee corporate responsibility policy, developing corporate responsibility values statements and publicising these within the industry, and seeking to embed independent feedback on the firm's ethical and environmental performance through internal training. Clearly, proactive awareness building mechanisms are able to convert positive corporate responsibility intentions into stronger relationships with suppliers.

We found that although monitoring corporate responsibility performance is important for distinguishing between available alternative supply partners and hence for selecting partners and developing partnerships, when buyers try to change existing behaviour through the promotion of corporate responsibility best practices it has a negative effect on relationship development, even in situations where the desired form of relationship is supply chain partnership.

Our findings confirm the importance of regular corporate responsibility monitoring in buyer-supplier relationship development. Monitoring is about examining how well the firm and those who supply to it are performing. Whilst closely associated with checking compliance, it is also about ascertaining if common attitudes towards corporate responsibility exist between buyer and supplier. That the monitoring of corporate responsibility performance is positively related to the incidence of the supply chain partnership approach within our sample, confirms the view that suppliers need to understand that their own corporate responsibility status and behaviour is an important consideration in supplier selection, and moreover in buyers' willingness or drive to establish more long term relationships with fewer suppliers.

The results do however suggest that suppliers are reluctant in a partnership situation to accept the buyers' promotion of best practices that it perceives would further enhance the ethical and environmental credentials of the partnership. It appears that when firms are in a partnership with their suppliers and try to get them to behave in a corporate responsible manner through the direct application of best practices the supply partners will resist it. Furthermore, this result also indicates that supply chain partnerships do not yet offer an effective vehicle for spreading corporate responsibility best practices. This negative impact of sharing corporate responsibility best practices and the incidence of the supply chain partnership approach is counter intuitive. The reason for this finding may lie in power distribution theory. Large organisations are more likely to enjoy greater power in a supply chain than smaller organisations. In turn large organisations are more likely to possess and/or be familiar with best practices. The literature suggests that asymmetric power has the potential to upset the mutuality of supply chain relationships and act as a barrier to win-win situations (Maloni and Benton, 2000). One manifestation of such asymmetry is to impose practices 
on suppliers and this may explain our finding. In any case we suggest that this finding is worthy of a more in-depth study.

Thirdly, we also examined the performance consequences of (a) corporate responsibility policy and practices within the supply chain and (b) adopting a supply chain partnership strategy. The former has received relatively little attention. We found no direct link between functional corporate responsibility policy and practices and firm performance. We did however find that the adoption of supply chain partnership has a direct effect on performance. This is commensurate with other work that examined the partnership-performance relationship (Carr and Pearson, 2002). Our findings therefore suggest that functional corporate responsibility policies and practices influence the functional strategy, in our case the conduct of supply chain strategy. The functional strategy in turn influences the firm performance. The link between functional strategy and performance supports the point of view exposed by a number of scholars (e.g., Hitt, et al., 1982; Schniederjans and Cao, 2009). The influence of corporate responsibility practices on performance is mediated through the functional strategy. Our finding suggests that unlike corporate level corporate responsibility practices, the impact of functional corporate responsibility practices is indirect. Corporate responsibility practices require allocation of resources and it may be necessary to justify such an allocation at the functional level. Our study suggests that this may not be directly possible, and in order to justify such expenditure it may be necessary to examine the impact on functional strategy and then the impact of the functional strategy on performance.

\section{Managerial implications}

In the marketplace, competition among firms continues to intensify. Amongst other things that have intensified the dual pressures on firms to protect their competitive position and reduce their transaction costs, is the need to demonstrate to their customers, wider marketplace and stakeholder group that they value and practice responsible corporate behaviour. Closer collaboration and dependence on a more efficient but flexible supply base is a common and pervasive route that firms use to address these dual pressures. Therefore, our findings provide some important implications for practitioners.

Firstly, suppliers wishing to become closer partners to their customers can enhance their prospects by showing their willingness to engage in regular independent audits of commercial and environmental integrity. Furthermore, their prospects can be augmented by developing ongoing monitoring practices to help them to ensure that their ethical and environmental behaviour meets desired targets, and by demonstrating their willingness to be part of ad hoc task groups to examine 
sensitive issues and areas identified by the ongoing monitoring practices. Secondly, firms wishing to extend the number of supply chain partnerships can enhance their prospects by introducing policies or engaging in activities that raise internal awareness of ethical and environmental responsibilities which convey to prospective partners the likelihood of receiving fair treatment.

Although we have no data for verification, a likely reason for supplier reluctance to develop (or strengthen) a partnership with a buyer that seeks to incorporate corporate responsibility best practices within the relationship is a perceived cost implication. It may be that adopting corporate responsibility best practices is viewed as expensive by suppliers and unnecessarily adding to their cost base. Simpson et al's (2004) study of environmental responsibility in SMEs, whilst not specifically focused on best practices has some parallels with these findings. They reported that meeting environmental good practice was seen as a cost that was not transferable to (in their case) customers in terms of added benefits. Our finding is however at odds with the literature that, although fragmented on the issue, points more to a positive relationship between corporate responsible performance and improved financial performance. Orlitzky et al's (2003) meta-analysis, for example, found that corporate virtue in the form of environmental and ethical responsibility is likely to pay off.

This finding, in turn, raises the question of whether or not there is a full understanding amongst supply managers that corporate responsibility can, in the long term, reduce costs. Our findings suggest not, and points to a need within the supply base for more education and familiarity of the wider economic benefits that a willingness to adopt corporate responsibility best practices can lead to. Our findings suggest that supply managers' appreciation of the business logic for adopting corporate responsible best practices is not yet sufficient (Salzmann et al., 2005), and highlights the need perhaps for a re-evaluation of what are the channels that can get this message across.

\section{Limitations and future research}

As an initial attempt to examine the relationship between corporate responsibility at the functional level of the firm, namely in the domain of supply relationships, our article is subject to several limitations.

Although our study is grounded with practitioner relevance, it examines what might only be a limited set of corporate responsibility awareness factors, monitoring practices and best practices, and additional factors should be uncovered and explored in the future. Our secondary research pointed to awareness, monitoring and sharing of best practices as the three key facets of corporate responsibility in the context of strategies and operating practices supporting buyer-supplier 
relationship development. However, there may be other constructs associated with corporate responsibility that were not within the scope of this study that need to be examined for their impact on partnership development and firm performance as their prevalence increases. For example, although not yet evident in the supply partnership context, the wider corporate responsibility literature recognises an emerging organisational learning curve for corporate responsibility (Zadek, 2008), and it is reasonable to propose that developing internal awareness could be complemented by developing learning and change management practices and/or developing schemes of reward and recognition specifically focused on embedding corporate responsibility in different functions of the firm and supporting external partnership development. More in depth case analyses, drawn from a wide spectrum of industrial and commercial sectors may expose further factors. It should also be highlighted that in this study we used two commonly used measures for firm performance. This was deliberate because we were interested in supply chain partnership's impact on the bottom line. Future research should use a wider set of measures for firm performance. In particular, future studies should consider the impact of supply chain partnership on more operations-based and market-based composite measures such as agility and time to market which were beyond the scope of this study.

Future research should investigate the reasons underpinning the apparent reluctance of supplier partners to strengthen the relationship through the acceptance of corporate responsibility best practices. One particular avenue that would extend our understanding of the specific nature of supply chain partnerships is to ascertain if this reluctance is predicated on economic reasons, or if in fact it has more to do with the supplier partner viewing such best practice initiatives as an attempt by the buyer to exert more control or increase their relative power within the partnership, and hence casting doubt for the supplier about the level of trust and long term commitment the buyer places in them.

We investigated the influence of corporate responsibility in one area of functional strategy in the firm, that of supply management. We focused on supply chain partnerships and found that corporate responsibility did have a positive influence, although in a limited sense. With these findings in mind, future researchers are encouraged to examine the influence of corporate responsibility in other functional areas of the firm. 
Corporate responsibility internal awareness*

1. designation of a senior manager with accountability for commercial values and ethics

2. a values statement and ethical framework on acceptable business practices

3. publicising ethical and environmental statements to stakeholders

4. incorporating findings of independent audits or monitoring practices within internal training programmes

Monitoring of corporate responsibility performance*

1. task group(s) to examine potentially sensitive areas

2. regular independent audits of commercial and environmental integrity

3. development of appropriate monitoring practices to ensure compliance with ethical policies

Sharing corporate responsibility best practices*

1. incorporating findings of independent audits or monitoring practices within training programmes with partners

2. using accreditation to ISO 14000 Series (Environmental Management Systems Standard) to distinguish preferred supplier status

3. incorporating ethical and environmental standards within partnering strategies

\section{Supply chain partnership}

1. the benefits from problem solving with main suppliers are always shared jointly

2. regularly involve suppliers in new product/service development

3. engage extensively in two way exchange of important/technical information with key suppliers

4. make long-term commitment to suppliers to achieve mutually acceptable outcomes

5. view our key suppliers as suppliers of capabilities, not merely products and services

\section{Performance}

1. sales per employee

2. profit margin

Notes: Sample size=152. *Adapted from Hughes et al, 1999. 


\section{References}

Ahmad, S. J., O'Regan, N., Ghobadian, A., 2003. Managing for performance: corporate responsibility and internal stakeholders. International Journal of Business Performance Management, 5(2-3), 141 153.

Akacum, A., Dale, B. G, 1995. Supplier partnering: Case study experiences. International Journal of Purchasing and Materials Management 31(1), 38-45.

Andriof, J., Waddock, S., 2002. Unfolding stakeholder engagement', in Andriof, J., Waddock, S., Husted, B., Sutherland, R. S. (Eds.). Unfolding Stakeholder Thinking. Greenleaf, Sheffield.

Baier, C., Hartmann, E., Moser, R., 2008. Strategic alignment and purchasing efficacy: an exploratory analysis of their impact on financial performance. Journal of Supply Chain Management 44(4), 36-52.

Banerjee, S. B., Iyer, E. S. and Kashyap, R. K., 2003. Corporate environmentalism: antecedents and influence of industry type. Journal of Marketing 67(2), 106-122.

Berman, S. L., Wicks, A. C., Kotha, S., Jones, T. M., 1999. Does stakeholder orientation matter? The relationship between stakeholder management models and firm financial performance. Academy of Management Journal 42(5), 488-506.

Boyd, D. E., Spekman, R. E. Kamauff, J. W., Werhane, P., 2007. Corporate social responsibility in global supply chains: a procedural justice perspective. Long Range Planning 40(3), 341-356.

Carr, A. S., Kaynak, H., Hartley, J. L., Ross, A., 2008. Supplier dependence: impact on supplier's participation and performance. International Journal of Operations and Production Management 28(9), 899-916.

Carlisle, Y.M., Faulkner, D.O., 2004. Corporate social responsibility: a stages framework. European Business Journal 16(4), 143-151.

Carr, A., Pearson, J., 2002. The impact of purchasing and supplier involvement on strategic purchasing and its impact on firm's performance. International Journal of Operations and Production Management 22(9), 1032-1053.

Carroll, A. B., 1979. A three-dimensional conceptual model of corporate performance. Academy of Management Review 4(4), 497-505.

Chauhan, S. S., Proth, J-M., 2005. Analysis of a supply chain partnership with revenue sharing. International Journal of Production Economics 97(1), 44-51.

Dillman, D. A., 2000. Mail and Internet Surveys: The Tailored Design Method. 2nd Ed. John Wiley Co., New York.

Dummett, K., 2006. Drivers of corporate environmental responsibility (CER). Environment, Development and Sustainability 8(3), 375-389.

Elbing, A. O., Elbing, C. J., 1964. The Value Issue in Business. McGraw-Hill, New York.

Eells, R., Walton, C., 1961. Conceptual Foundations of Business. Richard D. Irwin, Homewood. 
Fitzsimmons, J. A., Kouvelis, P., Mallick, D.N., 1992. Design strategy and its interface with manufacturing and marketing strategies: a conceptual framework. Journal of Operations Management 10(3), 398-415.

Fornell, C., Larker, D. F., 1981. Evaluating structural equation models with unobservable variables and measurement error. Journal of Marketing Research 18(1), 39-50.

Frederick, W. C., 1978. From CSR1 to CSR2: The maturing of business-and-society thought. Working Paper, University of Pittsburgh, Graduate School of Business.

Freeman, E. (1984). Strategic Management: A Stakeholder Approach. Basic Books, New York.

French, P., 1979. The Corporation as Moral Person. American Philosophical Quarterly 16(3), 207-215.

Friedman, M., 1962. Capitalism and Freedom. University of Chicago Press, Chicago.

Fynes, B., Voss, C. and de Burca, S., 2005. The impact of supply chain relationship dynamics on manufacturing performance. International Journal of Operations and Production Management 25(1), 6-19.

Gunasekaran, A., Patel, C., Tirtiroglu, E., 2001. Performance measures and metrics in a supply chain environment. International Journal of Operations and Production Management 21(1/2), 71-87.

Harrison, J. S., Bosse, D. A., Phillips, R. A., 2010. Managing for stakeholders, stakeholder utility functions, and competitive advantage. Strategic Management Journal 31(1), 58-74.

Hillman, A. J., Keim, G. D., 2001. Shareholder value, stakeholder management, and social issues: what's the bottom line? Strategic Management Journal 22(2), 125-139.

Hitt, M. A., Ireland, D. R., Stadter, G., 1982. Functional importance and company performance: moderating effects of grand strategy and industry type. Strategic Management Journal 3(4), 31- 330.

Hofer, C. W., Schendel, D., 1978. Strategy formulation: Analytical concepts. West Publishing, St. Paul. Holmberg, S., 2000. A systems perspective on supply chain measurements. International Journal of Physical Distribution and Logistics Management 30(10), 847-868.

Hopkins, M., 2005. Measurement of corporate social responsibility. International Journal of Management and Decision Making, 6(3-4), 213-231.

Hughes, J., Ralf, M., Michels, W., 1999., Transform Your Supply Chain, International Thomson, London.

Husted, B. W., 2003. Governance choices for corporate social responsibility: to contribute, collaborate or internalize?. Long Range Planning 36(5), 481-98.

Jones, T. M., 1995. Instrumental stakeholder theory: a synthesis of ethics and economics. The Academy of Management Review 20(2), 404-437.

Kumar, N., Stern, L. W., Anderson, J. C., 1993. Conducting interorganisational research using key informants. Academy of Management Journal 36(6), 1633-1651. 
Krause, D. R., Scannell, T. V., Calantone, R. J., 2000. A structural analysis of the effectiveness of buying firms' strategies to improve supplier performances, Decision Sciences 31 (1), 33-55.

Lambert, D. M., Emmelhainz, M. A., Gardner, J. T., 1996. Developing and implementing supply chain partnerships. The International Journal of Logistics Management 7(2), 1-17.

Laplume, A. O., Sonpar, K., Litz, R. A., 2008. Stakeholder theory: reviewing a theory that moves us. Journal of Management 34(6), 1152-1189.

Lebas, M. J., 1995. Performance measurement and performance management. International Journal of Production Economics 41(1-3), 23-35.

Levitt, T., 1958. The dangers of social responsibility. Harvard Business Review, 36(5), 41-50.

Li, S., Ragu-Nathan, B., Ragu-Nathan, T.S., Rao, S.S., 2006. The impact of supply chain management practices on competitive advantage and organizational performance. Omega 34(2), 107-124.

Madsen, H., Ulhoi, J. P., 2001. Greening of human resources: environmental awareness and training interests within the workforce. Industrial Management and Data Systems 101(2), 57-65.

Maloni, M., Benton, W. C., 2000. Power influences in the supply chain. Journal of Business Logistics, 21(1), 49-73.

Margolis, J. D., Walsh, J. P., 2003. Misery loves companies: rethinking social initiatives by business. Administrative Science Quarterly 48(2), 268-305.

McDonald, F., 1999. The importance of power in partnership relationships. Journal of General Management 25(1), 43-59.

McGuire, J. W., 1963. Business and Society. McGraw-Hill, New York.

McWilliams, A., Siegel, D., 2001. Corporate social responsibility: A theory of the firm perspective. Academy of Management Review 26(1), 117-127.

McWilliams, A., Siegel, D. S., Wright, P. M., 2006. Corporate social responsibility: strategic implications. Journal of Management Studies, 43(1), 1-18.

Mitchell, R. K., Agle, B. R., Wood, D. J., 1997. Toward a theory of stakeholder identification and salience: defining the principle of who and what really counts. The Academy of Management Review 22(4), 853-886.

Mohr, J., Spekman, R., 1994. Characteristics of partnership success: Partnership attributes, communication behaviour, and conflict resolution techniques, Strategic Management Journal 15(2), 135-132.

Morsing, M., Schultz, M., 2006. Corporate social responsibility communication: stakeholder information, response and involvement strategies. Business Ethics 15(4), 323-338.

Noci, G., 1997. Designing 'green' vendor rating systems for the assessment of a supplier's environmental performance. European Journal of Purchasing and Supply Management 3(2), 103 114. 
Orlitzky, M., Schmidt, F. L., Rynes, S. L., 2003. Corporate social and financial performance: a metaanalysis. Organization Studies 24(3), 403-441.

Park-Poaps, H., Rees, K., 2010. Stakeholder Forces of Socially Responsible Supply Chain Management Orientation. Journal of Business Ethics 92(2), 305-322.

Petts, J., Herd, A., Gerrard, S., Horne, C., 1999. The climate and culture of environmental compliance within SMEs. Business Strategy and the Environment 8(1), 14-30.

Pfeffer, J., Salancik, G. R., The External Control of Organizations: A Resource Dependence Perspective. Harper and Row, New York.

Porter, M., 1980. Competitive Strategy: Techniques for Analyzing Industries and Competitors. The Free Press, New York.

Preston, L. E., Post, J. E., 1975. Private Management and Public Policy. Prentice-Hall, Englewood Cliffs.

Salzmann, O., lonescu-somers, A., Steger, U., 2005. The business case for corporate sustainability: literature review and research options. European Management Journal 23(1), 27-36.

Schniederjans, M., Cao, Q., 2009. Alignment of operations strategy, information strategic orientation, and performance: an empirical study. International Journal of Production Research 47(10), 2535-2563.

Sharma, S., Vredenburg, H., 1998. Proactive corporate environmental strategy and the development of competitively valuable organizational capabilities. Strategic Management Journal 19(8), 729-753.

Simpson, M., Taylor, N., Barker, K., 2004. Environmental responsibility in SMEs: does it deliver competitive advantage?. Business Strategy and the Environment 13(3), 156-171.

Sohal, A. S., Perry, M., Pratt, T., 1998. Developing partnerships and networks: learning from practices in Australia. Technovation 18(4), 245-251.

Stuart, F. I., 1997. Supply-chain strategy: organizational influence through supplier alliances. British Journal of Management, 8(3), 223-236.

Sisodia, R., Wolfe, D. B., Sheth, J., 2007. Firms of Endearment: How World-Class Companies Profit from Passion and Purpose. Wharton School Publishing: Upper Saddle River, NJ.

Squire, B., Cousins, P.D., Brown, S., 2009. Cooperation and knowledge transfer within buyer-supplier relationships: the moderating properties of trust, relationship duration and supplier performance. British Journal of Management 20(), 461-477.

Stock, G. N., Greis, N.P., Kasarda, J. D., 2000. Enterprise logistics and supply chain structure: the role of fit. Journal of Operations Management 18(5), 531-4.

Stuart, F.I., 1997. Supply-chain strategy: organizational influence through supplier alliances. British Journal of Management 8(3), 223-36. 
Szwejczewski, M. Lemke, F., Goffin, K., 2005. Manufacturer-supplier relationships: An empirical study of German manufacturing companies. International Journal of Operations and Production Management. 25(9/10), 875-897.

Talluri, S., Sarkis, J., 2002. A model for performance monitoring of suppliers, International Journal of Production Research 40(16), 4257-4269.

Tan, K. C., Kannan, V. R., Handfield, R. B., 1998. Supply chain management: supplier performance and firm performance. International Journal of Purchasing and Materials Management 34(3), 2-9.

Taylor, B., 1971. The future development of corporate strategy. Journal of Business Policy 2(2), 2238.

Taylor, A., 2005. An operations perspective on strategic alliance success factors: an exploratory study of alliance managers in the software industry. International Journal of Operations and Production Management 25(5), 469-490.

Turban, D. B., Greening, D. W., 1997. Corporate social performance and organizational attractiveness. Academy of Management Journal 40(3), 658-672.

Tuten, T. L., Urban, D. J., 2001. An expanded model of business-to-business partnerships formation and success. Industrial Marketing Management 30(2), 149-164.

Vachon, S., Klassen, R. D., 2006. Extending green practices across the supply chain. International Journal of Operations and Production Management 26(7), 795-821.

Waddock, S., 2004. Parallel universes: companies, academics, and the progress of corporate citizenship. Business and Society Review 109(1), 5-42.

Waddock, S. A., Bodwell, C., Graves, S. B., 2002. Responsibility: the new business imperative. The Academy of Management Executive 16(2), 132-148.

Wartick, S. L., Cochran, P. L., 1985. The evolution of the corporate social performance model. Academy of Management Review 10(4), 758-770.

Williamson, O., 1985. The Economic Institutions of Capitalism. The Free Press, New York.

Wilson, D. T., 1995. An integrated model of buyer-seller relationships. Journal of the Academy of Marketing Science 23(4), 335-345.

Wood, D. J., (1991. Corporate social performance revisited. Academy of Management Review, 16(4), 691-718.

Wood, D. J., Jones, R. E., 1995. Stakeholder mismatching: A theoretical problem in empirical research on corporate social performance. The International Journal of Organizational Analysis, 3(3), 229-267.

Virolainen, V-M., 1998. A survey of procurement strategy development in industrial companies. International Journal of Production Economics 56-57, 677-688. 
Yamin, S., Gunasekaran, A., Mavondo, F. T., 1999. Relationship between generic strategy, competitive advantage and firm performance: an empirical analysis. Technovation 19(8), 507-18.

Zadek, S., 2004. The path to corporate responsibility. Harvard Business Review 82, 125-132.

Zineldin, M., Bredenlow, T., 2003. Strategic alliance: Synergies and challenges: a case of strategic outsourcing relationship "SOUR". International Journal of Physical Distribution and Logistics Management 33(5), 449-464. 
Table 1. Means, Standard Deviations (S.D.), and correlations

\begin{tabular}{|c|c|c|c|c|c|c|c|c|c|c|c|c|c|c|c|c|c|c|c|}
\hline & Mean & S.D. & 1 & 2 & 3 & 4 & 5 & 6 & 7 & 8 & 9 & 10 & 11 & 12 & 13 & 14 & 15 & 16 & 17 \\
\hline 1: IA1 & 3.52 & 1.06 & 1 & & & & & & & & & & & & & & & & \\
\hline 2: IA2 & 3.17 & 1.11 & $.386^{* *}$ & 1 & & & & & & & & & & & & & & & \\
\hline 3: IA3 & 2.97 & 1.17 & $.307^{* *}$ & $.612^{* \star}$ & 1 & & & & & & & & & & & & & & \\
\hline 4: IA4 & 3.13 & 1.03 & $.474^{* *}$ & $.632^{\star *}$ & $.578^{\star *}$ & 1 & & & & & & & & & & & & & \\
\hline 5: MT1 & 3.02 & 1.00 & $.500^{* *}$ & $.526^{\star *}$ & $.502^{\star *}$ & $.484^{* *}$ & 1 & & & & & & & & & & & & \\
\hline 6: MT2 & 3.09 & 1.00 & $.389^{* *}$ & $.515^{\star \star}$ & $.618^{\star *}$ & $.673^{* *}$ & $.455^{\star *}$ & 1 & & & & & & & & & & & \\
\hline 7: MT3 & 3.17 & 1.03 & $.434^{* *}$ & $.511^{* *}$ & $.575^{\star *}$ & $658^{* *}$ & $.441^{* *}$ & $.710^{* *}$ & 1 & & & & & & & & & & \\
\hline 8: SBP1 & 2.95 & 1.03 & $.394^{* *}$ & $.555^{\star \star}$ & $.567^{\star \star}$ & $.837^{\star \star}$ & $.451^{* *}$ & $.637^{* *}$ & $.675^{\star *}$ & 1 & & & & & & & & & \\
\hline 9: SBP2 & 2.81 & 1.21 & $.209^{* *}$ & $.453^{* *}$ & $.453^{\star *}$ & $.556^{* *}$ & $.345^{\star *}$ & $.419^{\star *}$ & $.413^{* *}$ & $.556^{* *}$ & 1 & & & & & & & & \\
\hline 10: SBP3 & 3.06 & 1.04 & $.442^{* *}$ & $.469^{\star *}$ & $.531^{* *}$ & $.657^{* *}$ & $.399^{* *}$ & $.569^{\star *}$ & $.613^{* *}$ & $.688^{* *}$ & $.583^{* *}$ & 1 & & & & & & & \\
\hline 11: SCP1 & 3.68 & 1.03 & 0.063 & 0.109 & 0.035 & 0.007 & 0.066 & $.149^{*}$ & $.173^{*}$ & 0.009 & -0.111 & -0.03 & 1 & & & & & & \\
\hline 12: SCP2 & 3.48 & 1.13 & 0.101 & 0.092 & 0.005 & 0.121 & 0.027 & 0.115 & $.205^{* *}$ & 0.103 & -0.053 & -0.006 & $.474^{* *}$ & 1 & & & & & \\
\hline 13: SCP3 & 2.98 & 1.34 & 0.033 & $.136^{*}$ & 0.034 & 0.059 & -0.015 & 0.102 & $.152^{*}$ & 0.075 & -0.029 & 0.029 & $.419^{* *}$ & $.645^{* *}$ & 1 & & & & \\
\hline 14: SCP4 & 3.34 & 1.18 & $141^{*}$ & 0.108 & 0.091 & 0.084 & 0.077 & 0.114 & $.191^{*}$ & 0.085 & -0.09 & -0.004 & $.388^{* *}$ & $.508^{* *}$ & $.596^{* *}$ & 1 & & & \\
\hline 15: SCP5 & 2.89 & 1.21 & 0.121 & $.234^{* *}$ & $.168^{*}$ & 0.114 & 0.064 & $.233^{* *}$ & $.225^{\star *}$ & 0.094 & -0.028 & 0.031 & $.497^{* *}$ & $.599^{* *}$ & $.628^{* *}$ & $.659^{* *}$ & 1 & & \\
\hline 16: PF1 & 1.70 & 0.74 & -0.102 & 0.035 & -0.049 & -0.087 & $-.150^{*}$ & -0.069 & 0.032 & -0.03 & -0.119 & -0.018 & 0.096 & 0.07 & $.198^{*}$ & $.212^{* *}$ & 0.101 & 1 & \\
\hline 17: PF2 & 1.77 & 0.76 & -0.026 & 0.106 & 0.007 & 0.058 & 0.076 & -0.041 & 0.005 & 0.04 & -0.103 & -0.028 & 0.059 & 0.089 & $.149^{*}$ & $.326^{* *}$ & $.191^{*}$ & 0.104 & 1 \\
\hline
\end{tabular}

Notes: Sample Size = 152; S.D. $=$ Standard Deviation; ${ }^{* *} P<0.01 ;{ }^{*} P<0.05$ (1-tailed)

$I A=$ Internal Awareness; MT = Monitoring; SBP = Sharing of Best Practices; SCP = Supply Chain Partnership; $P F=P e r f o r m a n c e$ 
Table 2. Results of Regression Analysis: Standardized Path Coefficients (t-Values)

\begin{tabular}{|c|c|c|}
\hline \multirow[t]{2}{*}{ Exogenous (controlled) Variables } & \multicolumn{2}{|c|}{ Endogenous Variables } \\
\hline & Supply Chain Partnership (SCP) & Performance (PF) \\
\hline \multicolumn{3}{|l|}{ Ethical behaviour } \\
\hline Internal Awareness (IA) & $0.221^{\star *}(2.032)$ & $0.108(1.272)$ \\
\hline Monitoring (MT) & $0.454^{* * *}(3.462)$ & $-0.159(-1.544)$ \\
\hline Sharing of Best Practices (SBP) & $-0.303^{* * *}(-3.952)$ & $0.008(0.151)$ \\
\hline Supply Chain Partnership (SCP) & --- & $0.221^{\star \star}(1.974)$ \\
\hline
\end{tabular}

Goodness of fit: $X 2(152)=184.041 P<0.001, C M I N / D F=1.688, I F I=0.940, C F I=0.938$,

RMSEA $=0.067$

Notes: Sample size $=152 . T$-tests are one-tailed for hypothesized effects and two-tailed for controls.

${ }^{* * *} P<0.01 ;{ }^{* *} P<0.05$ 